\title{
PENERAPAN TEKNIK "PASAR" DALAM PEMBELAJARAN BAHASA INDONESIA
}

\author{
oleh \\ Evi Yesifina Dumarista \\ Unika Atma Jaya Jakarta \\ fina.napituulu@gmail.com \\ fina.napitupulu@atmajaya.ac.id
}

\begin{abstract}
ABSTRAK
Penelitian ini berawal dari pengamatan peneliti terhadap respon dan minat mahasiswa Pendidikan Guru Sekolah Dasar (PGSD) dalam pembelajaran bahasa Indonesia di perguruan tinggi. Hasil angket atau kuesioner menyebutkan bahwa pengajaran dosen yang konvensional menjadi faktor utama mahasiswa kurang menyukai pembelajaran bahasa Indonesia. Di samping itu, materi yang kurang menarik atau tidak penting juga menjadi faktor pelengkap kurangnya kesadaran atau minat mahasiswa dalam menyikapi pembelajaran bahasa Indonesia. Dengan demikian, perlu adanya intervensi berupa suatu teknik agar pembelajaran bahasa Indonesia dapat menyenangkan dan efektif.

Adapun tujuan penelitian dari penerapan teknik "pasar" adalah untuk meningkatkan kemandirian, kecerdasan emosional, aspek kognitif, saling ketergantungan, multi sensasi, kesenangan, dan artikulasi. Sedangkan elemen yang diperoleh dalam aktivitas pembelajaran yaitu berupa kerja individu/kelompok, keterampilan berbicara, mendengarkan, membaca, menulis, dan melihat.

Peneliti menggunakan metode penyelidikan (inquiry learning) dalam kegiatan pembelajaran di kelas. Hasil data kuantitatif dan deskriptif dapat menjelaskan sintaks pembelajaran secara rinci. Dengan demikian berdasarkan hasil analisis data, peneliti menyimpulkan bahwa penggunaan teknik "pasar" efektif dalam meningkatkan tidak hanya minat, tetapi kreativitas mahasiswa untuk menentukan suatu pendekatan sampai media pembelajaran yang akan digunakan di kelas.

kata kunci: teknik "pasar"; Pembelajaran bahasa Indonesia
\end{abstract}

\section{PENDAHULUAN}

Pembelajaran merupakan suatu keseluruhan yang dilakukan di kelas. Hal tersebut meliputi tiga bagian penting yaitu pendahuluan, isi, dan penutup. Bagian isi dalam suatu pembelajaran merupakan pemerolehan informasi baru yang diterima oleh setiap siswa atau mahasiswa. Pemaknaan pembelajaran yang ada dalam bagian isi kegiatan memerlukan persiapan dari seorang dosen atau guru agar dapat menyampaikan informasi baru kepada mahasiswa atau siswanya. Akan tetapi, dosen atau guru sering kali mengabaikan hal tersebut sehingga kegiatan pembelajaran bahasa Indonesia menjadi kurang menarik dan membuat minat mahasiswa dalam belajar menjadi kurang kreatif dan kurang produktif. 
Pembelajaran bahasa Indonesia merupakan salah satu mata kuliah yang diajarkan hampir di seluruh perguruan tinggi negeri dan swasta di Indonesia. Hal ini bertujuan agar mahasiswa dapat memiliki keterampilan menulis baik menulis laporan, makalah, skripsi, jurnal, artikel, dan sejenisnya. Keterampilan menulis sangat penting dalam menunjang kemampuan mahasiswa mengembangkan dan mengemukakan ide atau informasi melalui tulisan. Bahkan dalam kenyataannya, masih banyak mahasiswa yang belum memiliki keterampilan menulis sehingga hal ini berdampak pada kesukaan atau minat mahasiswa dalam mempelajari bahasa Indonesia.

Pembelajaran bahasa Indonesia adalah salah satu mata kuliah yang ada di program studi Pendidikan Guru Sekolah Dasar (PGSD) Unika Atma Jaya. Mata kuliah ini terdiri atas empat SKS yang mana mensyaratkan bahwa mahasiswa diharapkan dapat memiliki dan meningkatkan kreativitas, inisiatif, kelogisan, dan berpikir kritis sehingga mampu menggali permasalahan, fenomena, atau kebaruan ilmu yang terdapat dalam pembelajaran bahasa Indonesia. Oleh karena itu, pembelajaran bahasa Indonesia yang dipelajari di perguruan tinggi semakin bermakna karena adanya beberapa hal tersebut.

Penerapan teknik "pasar" dilatarbelakangi untuk menjawab pertanyaan mengenai keefektivannya dalam pembelajaran bahasa Indonesia. Hal ini bertujuan agar pembelajaran yang dicapai mahasiwa mencakup pencapaian perubahan perilaku mahasiswa setelah mengikuti kegiatan belajar. Pencapaian ini berupa penambahan pemerolehan informasi, pemahaman pendekatan, strategi, metode, teknik, dan media pembelajaran yang digunakan, serta penilaian-penilaian dalam tugas, kuis, atau presentasi. Tujuan tersebut tentunya memerlukan suatu teknik sehingga tercapai sesuai harapan. Adakalanya tujuan pembelajaran tidak sesuai karena kurangnya persiapan dosen atau penguasaan materi yang masih minim sehingga memungkinkan mahasiswa untuk menyangkal atau membantah pendapat dosen tersebut.

Kurangnya minat mahasiswa dalam pembelajaran bahasa Indonesia dapat dilihat dari beberapa hal di antaranya sistem pengajaran konvensional yang diterapkan dosen di kelas. Akibatnya, mahasiswa tidak mendapatkan kesempatan untuk pengembangan diri. Selain itu, materi bahasa Indonesia yang telah diperolehnya sejak duduk di bangku sekolah dianggap telah mewakili pengetahuannya dalam belajar bahasa Indonesia. Padahal, mata kuliah bahasa Indonesia di perguruan tinggi atau khususnya pembelajaran bahasa Indonesia di program studi PGSD Unika Atma Jaya memiliki materi penting. Kedua alasan ini menjadi hal yang paling dominan dipilih mahasiswa sehingga berdampak pada kurangnya fokus atau minat dalam mendengarkan dosen menyampaikan materi di kelas. 
Penerapan teknik merupakan suatu hal yang sangat penting agar penyampaian ilmu atau materi bahasan dapat diserap dengan baik oleh mahasiswa. Joni dalam Abimanyu (2010:25) menyebutkan bahwa istilah teknik menunjuk kepada ragam khas penerapan sesuatu metode dengan latar penerapan tertentu, seperti kemamuan dan kebiasaan guru, ketersediaan peralatan, kesiapan siswa, dan sebagainya. Teknik pembelajaran "pasar" merupakan salah satu hal yang mampu meningkatkan kemampuan mahasiswa untuk memiliki kreativitas, kelogisan, dan kemandirian dalam pembelajaran bahasa Indonesia. Berdasarkan hal itu, peneliti mencoba untuk menguraikan penyebabnya dan mengaplikasikan salah satu teknik agar kegiatan pembelajaran bahasa Indonesia di PGSD Unika Atma Jaya dapat meningkatkan kreativitas, bermakna, dan meningkatkan pemahaman mahasiswa.

\section{METODE RISET ATAU PENELITIAN}

Variabel yang digunakan dalam penelitian ini memiliki definisi operasional yaitu teknik "pasar" dan pembelajaran bahasa Indonesia. Teknik "pasar" merupakan suatu teknik yang digunakan dengan konsep penjual, pembeli, dan barang dagangan. Ketiga konsep ini mewakili materi pembelajaran mengenai empat keterampilan berbahasa yaitu membaca, menulis, menyimak, dan berbicara. Keempat keterampilan berbahasa itu akan diaplikasikan dengan menggunakan pendekatan hingga media pembelajaran yang digunakan mahasiswa di kelas. Kemudian, pembelajaran bahasa Indonesia dapat didefinisikan sebagai salah satu mata kuliah wajib dikontrak oleh mahasiswa semester lima. Pembelajaran bahasa Indonesia dikhususkan untuk jenjang pendidikan sekolah dasar (SD).

Penelitian ini menggunakan metode deskriptif analitis. Metode deskripstif analitis adalah suatu cara menganalisis data dengan menggunakan penelitian kuantitatif atau kualitatif yang kemudian hasilnya dideskripsikan agar mendapatkan informasi sejelas-jelasnya. Dalam bagian ini akan dipaparkan beberapa hal terkait metode riset yang telah dilakukan.

Penelitian ini dilakukan selama satu bulan dengan objek penelitian adalah mahasiswa PGSD Unika Atma Jaya semester lima. Objek penelitian berjumlah 40 orang. Penelitian ini dilakukan pada tanggal 1-30 September 2017.

Kondisi kemampuan kecerdasan pada mahasiswa semester lima sangat beragam. Hal ini dapat dilihat dari pengamatan peneliti dalam melakukan kegiatan pembelajaran bahasa Indonesia. Peneliti menganggap pentingnya lembar kuesioner untuk mengetahui minat mahasiswa dalam pembelajaran bahasa Indonesia. Lembar kuesioner yang telah diperoleh menjadi data sekunder untuk menjadi tambahan informasi terhadap asumsi peneliti mengenai penerapan suatu teknik yang efektif.

Pengukuran yang dilakukan dalam penelitian ini meliputi pra tes, intervensi, pos tes, dan lembar evaluasi. Lembar evaluasi bertujuan untuk mengetahui tanggapan mahasiswa terhadap penerapan teknik "pasar" yang telah dilakukan 
dosen di kelas. Pengukuran dimaksudkan agar data yang terkumpul mewakili hasil dari intervensi yang dilakukan sehingga dapat diketahui keefektivan teknik "pasar". Bagan alur penelitian dapat dilihat sebagai berikut.

\section{BAGAN ALUR KEGIATAN PENELITIAN}

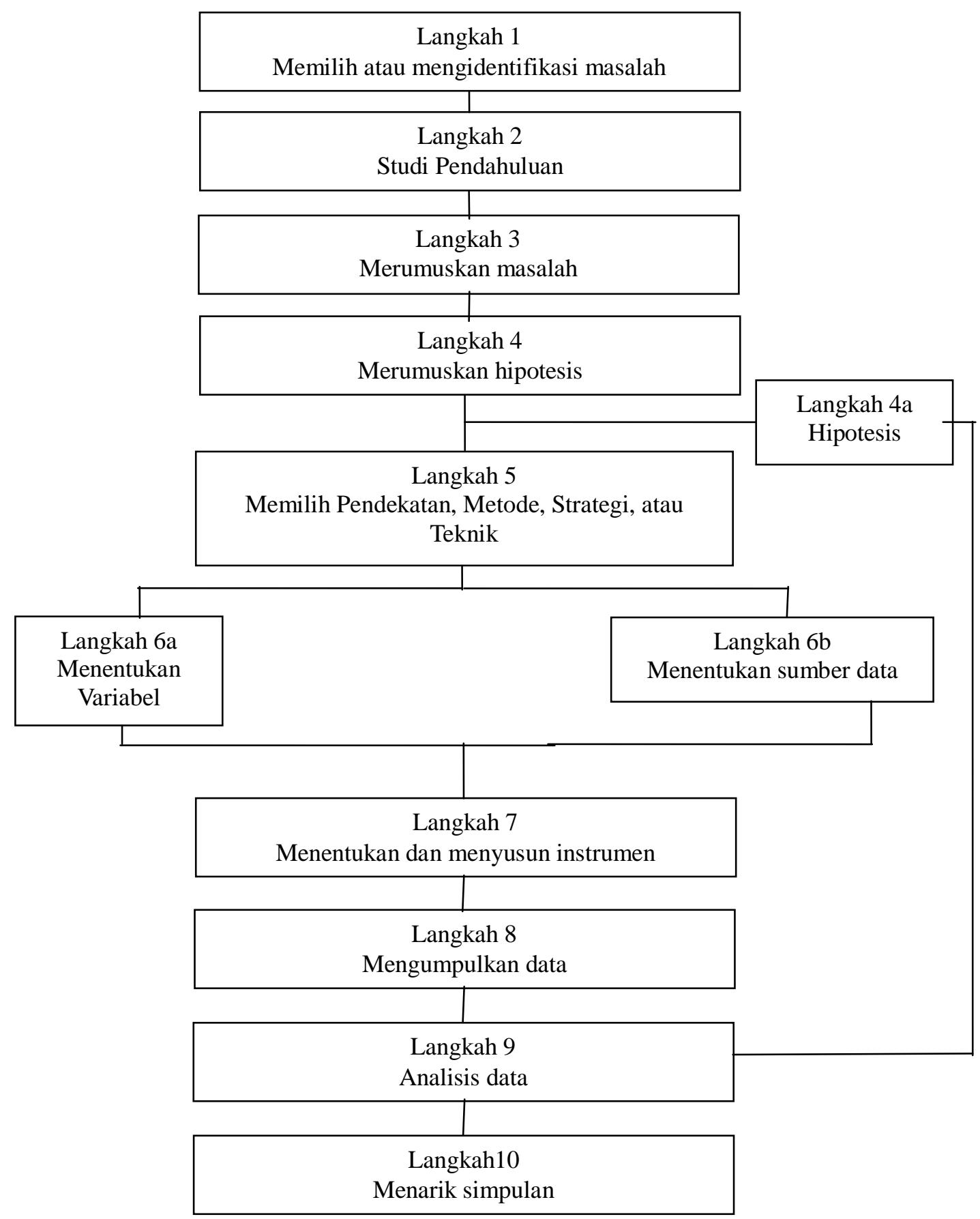




\section{HASIL DAN PEMBAHASAN}

Penelitian ini terdiri atas tiga tahap yaitu tahap pengambilan data awal, intervensi, pengambilan data akhir, dan pendeskripsian hasil analisis data. Pengambilan data diawali dengan pengumpulan informasi berupa observasi dan kuesioner. Lembar kuesioner memuat beberapa pertanyaan terkait penerapan teknik "pasar" dalam intervensi. Beberapa pertanyaan tersebut merupakan gambaran mengenai minat atau kesukaan mahasiswa terhadap pembelajaran bahasa Indonesia. Data tersebut dapat dilihat sebagai berikut. Berdasarkan data awal atau pra penelitian, peneliti memperoleh gambaran minat mahasiswa terhadap pembelajaran bahasa Indonesia pada grafik di bawah ini.

Grafik di atas menjelaskan empat faktor yang menjadi penyebab rendahnya

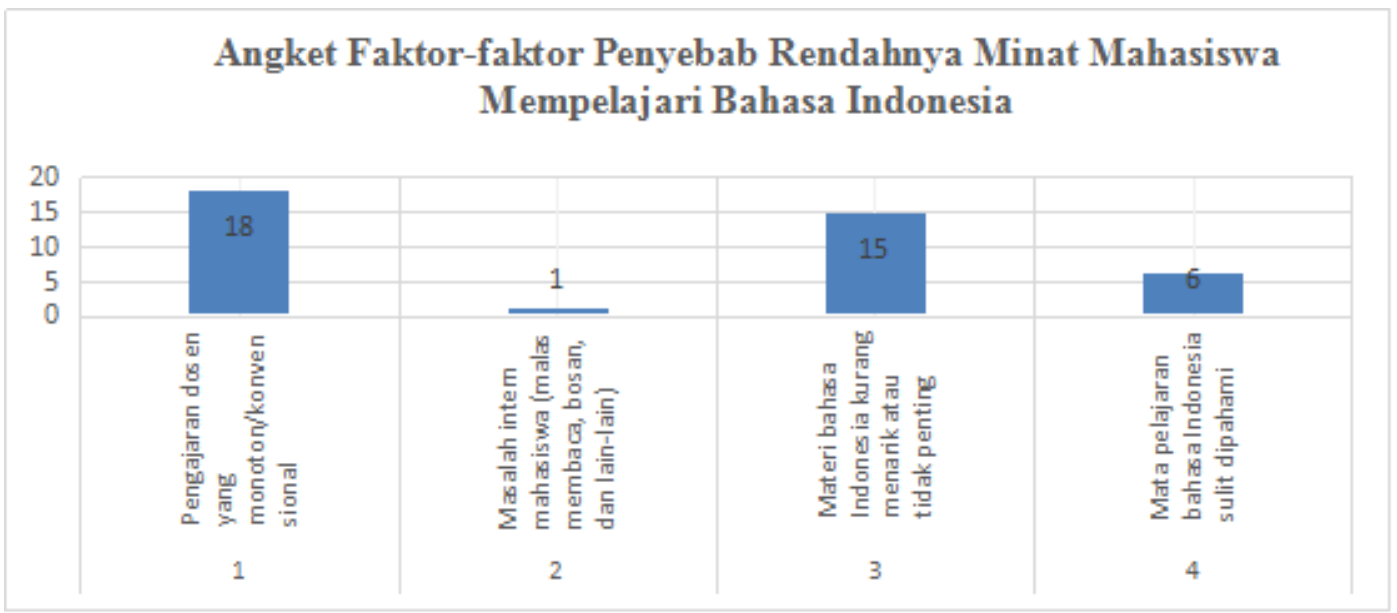

minat mahasiswa dalam mempelajari bahasa Indonesia di Fakultas Pendidikan Bahasa dan Seni Unika Atma Jaya. Keempat faktor tersebut terdiri atas hal-hal yang secara umum dapat diamati peneliti selama melakukan observasi awal di kelas. Empat faktor tersebut meliputi pengajaran dosen yang monoton atau konvensional, masalah intern mahasiswa, materi bahasa Indonesia yang kurang menarik atau tidak penting, dan mata pelajaran bahasa Indonesia sulit dipahami. Saat melakukan observasi untuk mengetahui keempat faktor tersebut, peneliti membuat beberapa pertanyaan yang tujuannya dapat mengidentifikasi penyebab rendahnya minat mahasiswa. Setelah data awal diolah, peneliti mengambil empat faktor utama atau penting yang paling banyak dituliskan oleh mahasiswa.

Berdasarkan grafik di atas, pengajaran dosen yang monoton menjadi faktor utama yang menjadi penyebab rendahnya minat mahasiswa. Kemudian disusul oleh penggunaan materi bahasa Indonesia yang kurang menarik atau tidak penting. Hal ini sangat dipengaruhi oleh faktor dosen dalam menjelaskan materi yang diajarkan. Dengan demikian, materi hendaknya disajikan dalam bentuk permasalahan atau ilmu baru sehingga mahasiswa mendapatkan wawasan keilmuan yang luas terkait 
materi tersebut. Faktor terakhir adalah mata kuliah bahasa Indonesia yang sulit dipahami dan masalah intern mahasiswa itu sendiri. Lembar kuesioner ini diberikan kepada 40 orang mahasiswa pendidikan guru sekolah dasar (PGSD) Unika Atma Jaya.

Tahapan di atas dapat dikatakan sebagai data awal peneliti untuk melakukan intervensi kepada mahasiswa. Dalam penelitian ini, peneliti membatasi materi yang dibahas di kelas yaitu mengenai empat keterampilan bahasa Indonesia. Keempat keterampilan bahasa tersebut kemudian dipadupadankan dengan menggunakan pendekatan, metode, strategi, teknik, trik, sampai dengan media pembelajaran. Dalam hal ini, peneliti memberikan kebebasan kepada mahasiswa untuk memilih materi atau tema yang dipilih, tetapi harus mengacu pada salah satu keterampilan berbahasa.

Sebelum melakukan intervensi, peneliti memberikan penjelasan terkait hal tersebut. Penjelasan meliputi defini empat keterampilan berbahasa, berbagai definisi pendekatan hingga media pembelajaran, sampai dengan peningkatan kreativitas mahasiswa. Hal ini bertujuan agar mahasiswa memiliki deskripsi umum untuk menggunakan berbagai pendekatan hingga media pembelajaran yang akan dipresentasikan di kelas. Acuan pengajaran materi empat keterampilan berbahasa adalah dari Tarigan. Di samping itu, berbagai literasi lainnya juga dipakai untuk menjelaskan mengenai pendekatan hingga media yang digunakan.

Peneliti melakukan tiga tahap selama melakukan penelitian. Tahap pertama peneliti mengobservasi, mengidentifikasi, dan memberikan kuesioner setelah melihat minat mahasiswa dalam belajar pembelajaran bahasa Indonesia di sekolah dasar (SD). Dalam tahapan ini, peneliti tidak menjelaskan sedang melakukan penelitian agar hasil yang diperoleh benar-benar dapat menentukan keefektivan teknik pembelajaran yang digunakan pada saat intervensi. Tahap kedua, peneliti menggunakan teknik "pasar" dalam melakukan intervensi kepada mahasiswa. Pada bagian ini, peneliti juga tidak memberitahukan tujuan melakukan intervensi dengan harapan yang sama pada tahap pertama.

Intervensi di mulai saat mahasiswa telah menentukan salah satu pendekatan hingga media pembelajaran yang akan digunakan pada salah satu keterampilan berbahasa. Kemudian, mahasiswa wajib memilih suatu materi atau tema dan mengaitkannya pada dua hal sebelumnya. Setelah hal itu dapat dikerjakan dengan baik dan menarik, mahasiswa pun dapat mengerjakan suatu media pembelajaran yang diharapkan dapat menjadi alat efektif dalam suatu pembelajaran bahasa Indonesia di sekolah dasar. Setelah mahasiswa selesai mengerjakannya, peneliti melakukan teknik "pasar" dengan memberikan syarat dan ketentuan kepada mahasiswa. Syarat dan ketentuan ini dapat dipahami dengan baik oleh mahasiswa sehingga penerapan teknik "pasar" dapat terlaksana dengan baik dan menarik. 


\begin{tabular}{|c|c|c|c|}
\hline No. & $\begin{array}{c}\text { Tahapan Penerapan } \\
\text { Teknik "Pasar" }\end{array}$ & $\begin{array}{l}\text { Waktu yang } \\
\text { ditentukan }\end{array}$ & Keterangan \\
\hline 1 & $\begin{array}{lr}\text { Dosen } & \text { menjelaskan } \\
\text { pembelajaran } & \text { mengenai } \\
\text { penggunaan pendekatan } \\
\text { hingga } \\
\text { pembelajaran media } \\
\text { menggunakan salah satu } \\
\text { keterampilan berbahasa. } \\
\text { Perlu diingat bahwa } \\
\text { penerapan teknik ini } \\
\text { adalah untuk merevisi } \\
\text { kegiatan pembelajaran } \\
\text { dan bukan untuk } \\
\text { mempelajari materi baru. }\end{array}$ & 1 menit & \\
\hline 2 & $\begin{array}{l}\text { Mahasiswa membuat } \\
\text { kelompok yang terdiri } \\
\text { atas tiga orang per } \\
\text { kelompok dan mengubah } \\
\text { materi dengan } \\
\text { menggunakan media } \\
\text { pembelajaran seperti } \\
\text { karton, ATK, poster, dan } \\
\text { sejenisnya. }\end{array}$ & 15 menit & \\
\hline 3 & $\begin{array}{lr}\text { Masing-masing } & \\
\text { kelompok } & \text { hanya } \\
\text { memberikan informasi } & \text { kepada } \\
\text { terbatas } & \text { kelompok lain. }\end{array}$ & 10 menit & $\begin{array}{l}\text { Di bagian inilah penggunaan } \\
\text { teknik "pasar" diaplikasikan. } \\
\text { Pengaplikasian teknik ini } \\
\text { sama dengan konsep pasar } \\
\text { sesungguhnya yaitu ada tiga } \\
\text { hal penting yang diperlukan } \\
\text { penjual, pembeli, dan barang } \\
\text { dagangan. Konsep penjual } \\
\text { artinya seorang mahasiswa } \\
\text { berperan menjajakan barang } \\
\text { dagangannya kepada } \\
\text { pembeli. Barang dagangan }\end{array}$ \\
\hline
\end{tabular}




\begin{tabular}{|c|c|c|c|}
\hline & & & $\begin{array}{l}\text { ini merupakan materi atau } \\
\text { tema pelajaran yang telah } \\
\text { ditentukan. Kemudian, } \\
\text { anggota kelompok lain } \\
\text { berperan menjadi pembeli } \\
\text { untuk memperoleh } \\
\text { informasi dari tempat lain. }\end{array}$ \\
\hline 4 & $\begin{array}{l}\text { Masing-masing } \\
\text { kelompok kembali ke } \\
\text { home base. }\end{array}$ & 10 menit & $\begin{array}{l}\text { Kelompok yang terdiri atas } \\
\text { penjual dan pembeli kembali } \\
\text { ke home base-nya. Pembeli } \\
\text { yang telah memperoleh } \\
\text { informasi baru dari tempat } \\
\text { lain diharapkan dapat } \\
\text { menjelaskan kepada anggota } \\
\text { kelompok yang bertugas } \\
\text { sebagai penjual. Dengan } \\
\text { demikian, baik penjual } \\
\text { maupun pembeli } \\
\text { memperoleh informasi yang } \\
\text { sama mengenai pendekatan } \\
\text { hingga media pembelajaran } \\
\text { yang digunakan oleh } \\
\text { kelompok lain. }\end{array}$ \\
\hline 5 & $\begin{array}{lr}\text { Dalam tahapan ini, } \\
\text { semua catatan, poster, } \\
\text { materi atau media } \\
\text { pembelajaran yang } \\
\text { digunakan disingkirkan. } \\
\text { Tujuannya agar peneliti } \\
\text { dapat mengukur } \\
\text { keterpahaman } \\
\text { mahasiswa ralam } \\
\text { memaknai pendekatan } \\
\text { hingga } \\
\begin{array}{l}\text { pembelajaran yang telah } \\
\text { diaplikasikan di kelas. }\end{array}\end{array}$ & 10 menit & \\
\hline
\end{tabular}




\begin{tabular}{|l|l|l|l|}
\hline & $\begin{array}{l}\text { Bagian ini adalah akhir } \\
\text { dari penerapan teknik } \\
\text { "pasar" yaitu tiap } \\
\text { kelompok } \\
\text { menggabungkan } \\
\text { pikirannya dan } \\
\text { mempresentasikannya di } \\
\text { kelas. Hal itu dilakukan } \\
\text { secara bergantian dengan } \\
\text { kelompok lainnya. }\end{array}$ & \\
\hline
\end{tabular}

Kegiatan penerapan teknik "pasar" dalam pembelajaran bahasa Indonesia dilaksanakan melalui serangkaian tahap dengan batasan waktu yang telah ditentukan sebelumnya oleh peneliti sebagai dosen. Jumlah tahapan dan batasan waktu dari masing-masing kelompok bervariasi berdasarkan topik, kerumitan materi, dan kesiapan mahasiswa dalam membuat pengajaran yang menarik di kelas. Penerapan teknik ini dapat dilihat pada tabel di bawah ini.

Kegiatan di atas membutuhkan waktu sekitar 40 menit. Akan tetapi, peneliti mengelaborasi dan mengeksplorasi teknik "pasar" dengan penggunaan durasi waktu empat SKS atau setara dengan waktu tiga jam dua puluh menit. Dalam pelaksanaannya, peneliti juga melakukan identifikasi terhadap kelebihan dan kelemahan penggunaan teknik ini di kelas. Salah satu kelemahan dari penerapan teknik ini adalah kebisingan volume suara mahasiswa dalam menjelaskan salah satu pendekatan hingga media yang digunakan antara satu kelompok dengan kelompok lainnya. Hal ini perlu dilakukan evaluasi seperti pemilihan tempat atau ruangan kelas yang lebih besar atau out door. Sementara itu, peneliti mengasumsikan salah satu kelebihan penerapan teknik "pasar" adalah mahasiswa memperoleh pemahaman yang benar mengenai penggunaan pendekatan hingga media dan peningkatan kreativitas ide atau gagasan.

Setelah melakukan penerapan teknik "pasar", peneliti memberikan tes untuk dapat mengukur dan mengevaluasi penggunaan teknik tersebut. Hasil tes tersebut dapat dilihat sebagai berikut.

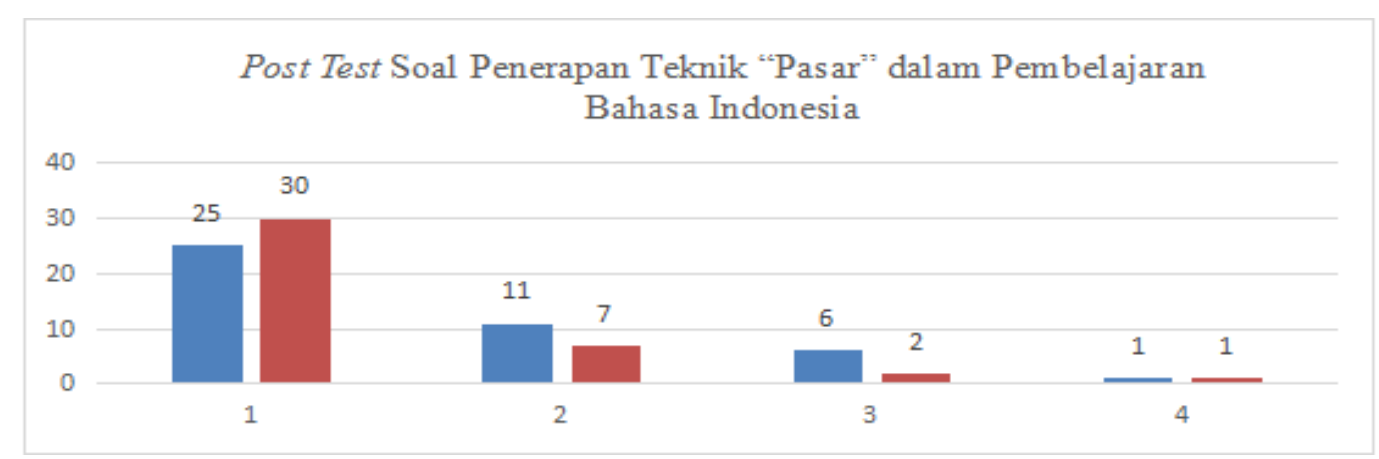


Diagram batang di atas memuat dua pertanyaan yang menjadi post test selelah diterapkannya intervensi. Kedua pertanyaan tersebut mencakup definisi pendekatan hingga media pembelajaran dan rancangan sintaks atau langkah-langkah pembelajaran dengan kriteria tertentu. Hasil di atas menjelaskan bahwa terdapat 25 orang yang dapat menjawab dengan tepat, 11 orang cukup tepat, 6 orang kurang tepat, dan satu orang tidak tepat. Begitu pula pada pertanyaan kedua terdapat 30 orang menjawab tepat, 7 orang cukup tepat, 2 orang kurang tepat, dan satu orang menjawab tidak tepat. Dengan demikian, penerapan teknik ini cukup efektif dalam pembelajaran bahasa Indonesia khususnya pada bagian pengenalan mengenai berbagai pendekatan hingga model pembelajaran yang digunakan di kelas.

Sanjaya (2008:241) menyebutkan bahwa evaluasi merupakan suatu proses. Artinya dalam suatu pelaksanaan evaluasi seharusnya terdiri atas berbagai macam

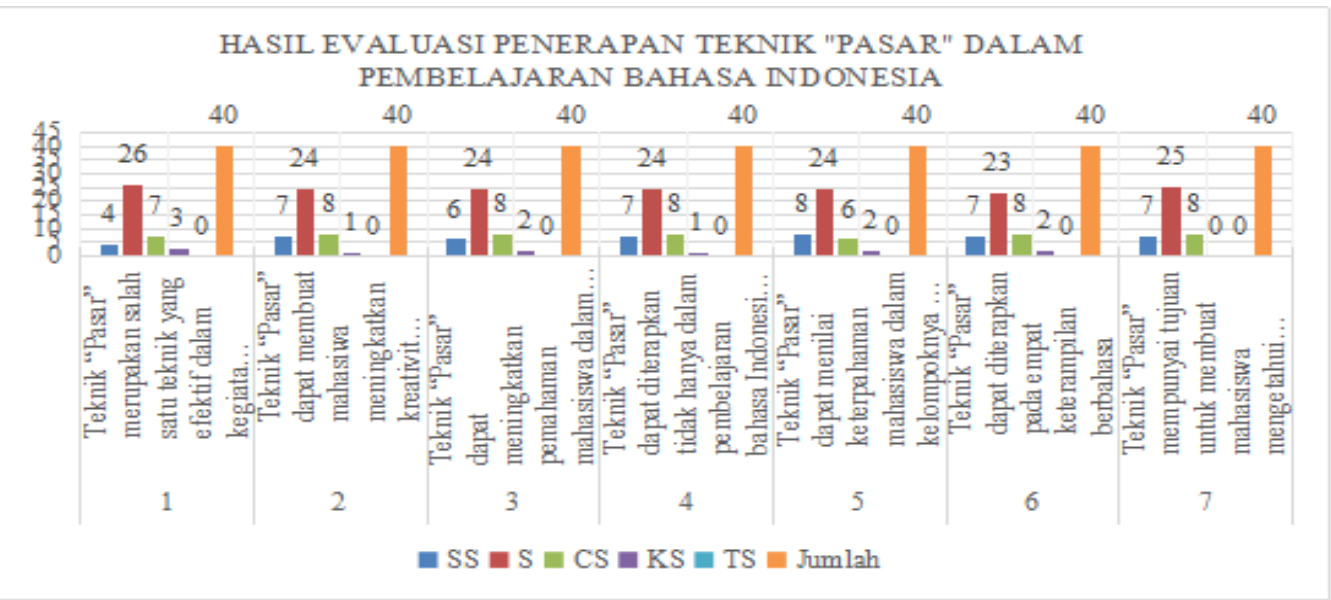

tindakan yang harus dilakukan. Tindakan tersebut bertujuan untuk memberi makna atau nilai sesuatu yang dievalusi. Nilai sesuatu yang dimaksudkan adalah penerapan teknik "pasar. Oleh sebab itu, langkah terakhir untuk mengetahui keefektivan penerapan teknik "pasar" ialah dengan menggunakan lembar evaluasi pembelajaran. Hal ini berarti pertanyaan yang diajukan terkait dengan teknik tersebut. Selain itu, lembar evaluasi ini juga dapat digunakan sebagai alat untuk melakukan refleksi terhadap teknik yang digunakan dan pembelajaran bahasa Indonesia khususnya pada mahasiswa PGSD Unika Atma Jaya. Hasilnya dapat dilihat sebagai berikut.

Hasil evaluasi di atas terdiri atas tujuh pertanyaan dan jawaban yang terdiri atas SS (Sangat Setuju), S (Setuju), CS (Cukup Setuju), KS (Kurang Setuju), dan TS (Tidak Setuju). Mahasiswa memberikan jawaban beragam terhadap pertanyaan pertama sampai dengan ketujuh. Mahasiswa yang menjawab SS (Sangat Setuju) pada pertanyaan pertama hingga ketujuh terdiri atas 4 orang, 7 orang, 6 orang, 7 orang, 8 orang, 7 orang, dan 7 orang. Kemudian pada kategori jawaban S (Setuju) 
terdiri atas 26 orang, 24 orang, 24 orang, 24 orang, 24 orang, 23 orang, dan 25 orang. Kemudian sebanyak 7 orang, 8 orang, 8 orang, 8 orang, 6 orang, 8 orang, dan 8 orang dalam pertanyaan pertama hingga ketujuh menjawab CS (Cukup Setuju). Dengan demikian pada kategori KS dan TS hanya sedikit mahasiswa yang memberikan jawabannya. Dengan demikian, peneliti menyimpulkan bahwa hasil lembar evaluasi terhadap penerapan teknik "pasar" dapat mewakili keefektivannya dengan cukup baik dan menarik dalam pembelajaran bahasa Indonesia.

\section{DAFTAR PUSTAKA}

Abimanyu dkk. 2010. Strategi Pembelajaran. Jakarta: Direktorat Jenderal Pendidikan Tinggi Kementrian Pendidikan Nasional.

Arikunto, Suharsimi. 2002. Prosedur Penelitian: Suatu Pendekatan Praktik. Jakarta: PT Rineka Cipta.

Ginnis.2008. Trik dan Taktik Mengajar. Jakarta: PT Indeks

Saadie. 2008. Strategi Pembelajaran Bahasa Indonesia. Jakarta: Universitas Terbuka

Sanjaya. 2008. Perencanaan dan Desain Sistem Pembelajaran. Jakarta: Kencana Perdana Media Group.

Subana dan Sunarti. 2011. Strategi Belajar Mengajar. Bandung: CV PUSTAKA SETIA

Suyadi. 2013. Strategi Pembelajaran Pendidikan Karakter. Bandung: Rosdakarya Offset.

Tarigan. 2009. Strategi Pengajaran dan Pembelajaran Bahasa Indonesia. Bandung: Penerbit Angkasa 